\title{
Ellipsis As Aesthetic Formal Marker of the Short Story Das Brot
}

\section{Rosyidah \\ Universitas Negeri Malang}

\section{Abstract}

In the short story Das Brot, the use of ellipsis is dominant. Therefore, it is considered as formal aesthetic marker of this literary text. This paper is based on the results of the research which aimed (1) to describe the ellipsis used by the author in the short story and (2) to describe the aesthetic functions of these ellipsis. Analysis covered all syntactically incomplete sentences in the short story. Furthermore, the aesthetic functions of the ellipsis were analysed qualitatively. The research concludes that in the short story, ellipsis refer to sentences without subject and predicate; subject, predicate and predicative adjectivephrases; subject, predicate and object; object; adverbs and also sentences without main clause. The research results also show that the ellipsis in the short story have aesthetic interactive functions which relate to intersubjectivity and continuer. Moreover, it has also communicative functions, specifically expressive, assertive and directive functions.

In the short story Das Brot, the use of ellipsis is dominant. Therefore, it is considered as formal aesthetic marker of this literary text. This paper is based on the results of the research which aimed (1) to describe the ellipsis used by the author in the short story and (2) to describe the aesthetic functions of these ellipsis. Analysis covered all syntactically incomplete sentences in the short story. Furthermore, the aesthetic functions of the ellipsis were analysed qualitatively. The research concludes that in the short story, ellipsis refer to sentences without subject and predicate; subject, predicate and predicative adjectivephrases; subject, predicate and object; object; adverbs and also sentences without main clause. The research results also show that the ellipsis in the short story have aesthetic interactive functions which relate to intersubjectivity and continuer. Moreover, it has also communicative functions, specifically expressive, assertive and directive functions.

Keywords: ellipsis, formal aesthetic marker, function, short story Das Brot

\section{Background}

Ellipsis is a cohesion device that is also recognized as a formal aesthetic marker of literary texts. As a formal aesthetic marker, an ellipsis is characterized by a sentence 
that is grammatically incomplete or shortened and is used by the author of a literary work dominantly.

In the short story Das Brot, one of the literary works of Wolfgang Borchert (1946), a young German author who was phenomenal in the post-World War II era, the use of ellipsis is remarkable. Therefore, ellipsis is considered as one of his writing styles of the 735 words short story. As a formal aesthetic marker or as a writing style, ellipsis in literary texts can have a certain effect on the reader. In other words, the choice of ellipsis as a style by the author is not just because the author likes it, but because ellipsis can help the author deliver the message in a way that is showy and alluring, so that it attracts the reader's attention. The nuances created by using ellipsis may not be achieved through other styles.

According to Halliday \& Hassan (1976: 88), ellipsis is "the form of substitution in which the item is replaced by nothing", while Mahalli, Vapori and Mahdavi (2016: 79) stated that "a linguistic feature leaving out certain linguistic elements and yet reveals the meaning of the original text". That means, ellipsis is a feature of language in the form of abbreviation /shortening of sentences that is done by slipping a part or some parts of the sentence without reducing the meaning of the complete sentence.

Halliday \& Hassan (1976) and Jabeen, Mehmood and Iqbal (2013) stated that ellipsis sentences can be classified based on the omitted part into three types, namely nominal, verbal, and clausal ellipsis. The nominal ellipsis refers to the reduction/impingement of nominal noun/phrase which also involves deiksis, number, and epitet. Verbal ellipsis is a verbal/verbal phrase reduction/ perception. The clausal ellipsis relates to the imposition of clauses which include the elements of modal and proposition.

The classification of ellipsis with different viewpoint was presented by Busler and Schlobinski (1996) which distinguished three types of pragmatic and syntactic ellipsis sentences, namely Sprechhandlungsellipse, Adjazenzellipse, and Koordinationsellipse. Sprechhandlungsellipse refers to the communication function (directive, assertive, and expressive), for example, Meiner Tochter eine Cola 'For my daughter a cola'. The example is an imperative sentence, thus it has a directive function, delivered by a father/mother to a waiter in a restaurant and can only be fully reconstructed through an analysis of the context of the situation. The complete reconstructed sentence is Bringen Sie meiner Tochter eine Cola mit! or Sie sollen meiner Tochter eine Cola mitbringen 'Please bring a Cocacola for my daughter!' or in Indonesian 'Tolong bawakan cocacola untuk anak saya'.

Adjazenzellipse is an ellipsis which can be reconstructed either pragmatically or syntactically by referring subsequent or previous sections (Busler and Schlobinski, 1996), 
for example Je nachdem, [ob du die Aufgabe fertig machst oder nicht] which can be paired with It all depends, [whether your duty finished or not]. Notice the difference with the following example. Ich esse gern Reis, du [isst gern] Brot 'I like to eat rice and you [like to eat] bread'.

Coordinationsellipse is an ellipsis sentence that refers to the reduction of equal parts within the framework of the coordinating structure (Klein, 1985; Busler and Schlobinski, 1997; Bonitz, 2013). They also explained that this ellipsis consists of Phrasenkoordination and Satzkoordination. According to Lotze (2011), Phrasenkoordination is an ellipsis characterized by the existence of parts of the sentence (constituent) which are identical and connected through the conjunction, but the identical part is deleted. For example, Die alte [Dame] und die junge Dame singen that can be paired into English become Old [woman] and young woman sing or into Indonesian Wanita tua dan [wanita] muda menyanyi. Meanwhile, Satzkoordination can be interpreted as merging two (or more) independent sentences by using conjunctions and dissipating the same parts. For example, Die alte Dame singt und die junge [Dame] auch [singt] 'The old woman sings and the young [woman sings] too. In ellipsis, in general, parts of sentences that are omitted are the same information and are considered redundant or unimportant (Dwivedi, 2015). Absorption/shortening is done to reinforce the effect of the message conveyed by the author. For example, Je früher der Abschied [ist], desto kürzer [ist] die Qual 'The sooner the farewell [is], the shorter [is] the agony '. In that example, the deleted parts are placed in brackets to explain that they are verbs or predicates of the sentences. Although an important part of the sentence, namely the verb/predicate is omitted, the readers can understand what is meant by that statement..

Related to the function of ellipsis, according to Halliday and Hassan (1976), although ellipsis contains structural inequalities, the facts show that ellipsis is understandable because the language function in its usage situations actually refers to the text so that even if it is not said or written, the ellipsis information usually can still be completed by referring to the corresponding structure in the nearest context.

Ellipsis is often used both in conversation and in writing, both in literay texts and in non-literary texts. Generally, the use of ellipsis in the literary texts, both oral and written literature, is to engage the listeners or readers with their imagination, by finding out deliberately a word or phrase omitted by the author. In connection to that, Busler and Schlobinski (1997), White (2015) elaborated the function of ellipsis. Busler and Schlobinski stated that ellipsis has the communicative function (directive, assertive and expressive). Meanwhile, according to White, ellipsis has interactive functions, namely intersubjectivity, continuer and correction. In literary works, there are two main functions of 
ellipsis, namely as a device of cohesion and as a device of style. As a device of cohesion, ellipsis is a link to the section before or after. As a device of style, ellipsis is the way which the author chooses to express his ideas and emotions.

In addition, ellipsis is also widely used in German idioms, both classical and modern. Example: Erst [kommt] die Arbeit, dann [kommt] das Vergnügen. The example is an idiom that shows a very famous German work ethic (working first, then having fun). In the idiom, it can be seen that the part that does not appear is a verb/predicate. The statement is affirmed and the idiom is shortened. Ellipsis like this is commonly used in the language of association or as a motto.

Based on the above description, ellipsis is any sentence that is not grammatically complete. This incompleteness can be caused by the shortening or omitting of certain parts which are considered to be of little importance with the purpose of suppressing the parts raised which are assumed to be understood by the readers. The forms of ellipsis as the style of the author's language can be easily identified, i.e. if there is the absence of some or part of the sentence at once which is considered unimportant. In other words, the author only writes the most important parts or the focus of feelings and language. Besides that, ellipsis also has another meaning, namely the emptying of information by the author, either intentionally or not. In accordance to that explanation, Dwivedi (2015) stated "The economy of statements motivates the language users to employ ellipsis whenever and wherever it is feasible". Freely, it can be understood that the principle of speaking economically motivates language users to use ellipsis whenever and wherever it is possible.

Research on the use or rather the function of ellipsis linguistically has been widely discussed, including in German language. There are many researchers on German ellipsis such as Lotze (2011), Müller (2014) and Menzel (2016). But there are not yet many researchs about ellipsis and its functions in literary texts. Sofar I know, there are only a few research results reported. Cardin (2008) studied figures of silence: ellipses and eclipses in John McGahern's collected stories and Dwivedi (2015) conducted a research on ellipsis in English and Hindi short stories. Based on the fact, studies on ellipsis and its function in literary texts are still needed and should be conducted to enrich discussing materials in this field, in particular in German context. Therefore, this research on German ellipsis as a dominant style in the short story Das Brot is useful and important to do. 


\section{Method}

This research is a qualitative research that aims at describing the ellipsis in the short story Das Brot and its function. This research produced descriptive and reflective verbal data. Descriptive verbal data refer to the types of ellipsis in the short story which also becomes the data source and their functions, while reflective data are derived from field notes made by researchers related to the research situation and comments about data and research data sources at the time of the research.

All data were collected by document analysis and note-taking. Important steps in analyzing document and note-taking techniques in this research include (1) reading the entire short story documents over and over; (2) marking words, phrases, clauses, and sentences that belong to the data in the short story; (3) creating categories and data codes; (4) classifying data; (5) grouping data with ascending program; dan (6) entering data into tables.

The data were analysed interactively during and after data collection by using the sociosemiotic model of Halliday (1978), better known as contruct and context analysis. In this sociosemiotic analysis, the construct contains three elements, namely field (field, subject matter, purpose), tenor (general atmosphere), and mode (way).

During the research process, the researcher was present and acted as key instrument in collecting, analyzing, and interpreting research data. To facilitate the researcher in conducting this research, she developed simple research instruments in form of field notes and data tables.

\section{Results and Discussion}

\subsection{Ellipsis in the short story Das Brot}

The results of data analysis show that in the short story Das Brot there are 14 ellipsis sentences. Based on parts of sentences omitted, ellipses in the short story Das Brot can be classified into six types, namely (1) ellipsis of subject and predicative, (2) ellipsis of subject and predicate, (3) ellipsis of subject, predicate and object, (4) ellipsis of object, (5)) ellipsis of adverb and (6) ellipsis of main clause/sentence. 


\subsection{Ellipsis of subject and predicative}

In the short story Das Brot, the ellipsis of subject and predicative appears in the following forms.

1. Nachts, um halb drei.

2. In der Küche.

\section{So barfuß auf den kalten Fliesen}

\section{Dreiundsechzig.}

In ellipsis (1), the sentence is only an adverb of time. The ellipsis consists of two exadverbs that indicate time, that is Nachts 'At night' and um halb drei 'at half past three'. Ellipsis (2) consists also of an adverb that refers to place, In der Küche 'In the kitchen' From the reconstruction of the ellipsis (1) and (2), syntactically and contextually, it can be identified that the deleted parts of both sentences are the subject es 'it' or das 'that' and predicative war 'was' or passierte 'happened.' Thus, the complete sentences, the results of the reconstruction for both ellipsis are [Es war] nachts, um halb drei. [Es war] in der Küche. Stylistically, both ellipsis are used by the author to emphasize the background of the story to the readers so that it can bring a strong effect. This is indicated by the repeated mention of the words used in both ellipsis.

A similar case occurs in ellipsis (3) which is also just an adverb. The adverb so barfuß is a modal adverb, while auf den kalten Fliesen is a local adverb. Overall, the ellipsis means barefoot on a cold floor. Unlike the previous two ellipsis, ellipsis (3) is used in a conversation between husband and wife, the characters in the short story. Contextually, both pragmatic and syntactic styles, it informs that the missing part of the sentence is the subject $d u$ as a form of intimate addressing and bist or stehst as predicate. The complete reconstructed sentence is: [Du bist/stehst] so barfuß auf den kalten Fliesen. ['You are/stand] so barefoot on the cold floor'This ellipsis is used in dialogue with intimate language variety between husband and wife as the story characters. In this case, the ellipsis is used by the wife deliberately to express her concern/feel anxiously to her husband who is barefoot on a cold floor. Thus, the ellipsis has an expressive function as Busler and Schlobinski (1996) explained. Beside that, ellipsis (3) is clearly a formal marker of verbal interaction and an effective strategy of saving words and time in pragmatic communication (White, 2013).

Ellipsis (4) consists of only one word, a number. From the context, it can be known that the number refers to the age, as revealed in the antecedent sentence, i.e.... dass er 
nachts im Hemd doch schon recht alt aussah. So alt wie er war. Therefore, syntactically, ellipsis (4) can be reconstructed into [Er war] dreiundsechzig. In other words, the missing part of the ellipsis is the subject er and the predicate war. Stylistically, the ellipsis is used by the author to express the thoughts and feelings of the wife's character about her husband who is no longer young, 63 years old. Thus, this ellipsis (4) shows an expressive function (Busler and Schlobinski, 1996).

\subsection{Ellipsis of subjekt and predicate}

Ellipsis of subject and predicate is also present in Das Brot. Notice the following form!

(5) "Nacht," antwortete er und noch: "ja, kalt ist es schon ganz schön."

Ellipsis (5) is located in the middle of the phrase "Nacht," antwortete er und noch: "ja, kalt ist es schon ganz schön." and therefore it can not be seen at first glance as an ellipsis. However, through syntactic and contextual analysis it is ensured that the conjunctor und is used as a liaison between sentences or words. In the existing context, the antecedent is a sentence so that the word noch is an ellipsis form of the phrase ... und noch [antwortete er]:... Stylistically, the ellipsis is used intentionally to avoid repeating the same words so that the sentence is not monotonous. The function of this ellipsis, as indicated by the complete sentence is continuer, one of interactive functions (White, 2013).

\subsection{Ellipsis subject, predicates and objects}

In the short story Das Brot, there is also an ellipsis formed by eliminating/ deleting subjects, predicates, and objects. The ellipsis appears in the following forms.

(6) Jeden Abend.

(7) Gute Nacht

(8) "Nacht,"

(9) Doch.

Ellipsis (6), Jeden Abend 'every night', is just an adverb of time. However, based on the context it can be recognised that the complete sentence is [Sie machte es] jeden Abend '[She did it] every night'. Therefore, the omitted part in the ellipsis is a clause consisting of the subject sie 'she', predicate machte 'did' and the object es 'it.'. The ellipsis is used 
by the author of Das Brot to omit the same and redundant parts., as well as to express and highlight important new information that every night the character clean and tidy up the table. Hence, the ellipsis has an expressive function.

Ellipsis (7) and (8) are the same utterance commonly used in German as a general farewell at night and especially before bed. Both ellipsis is derived from the same sentence, namely Ich wünsche dir eine gute Nacht 'I wish you a good night'. Thus, ellipsis (7) can be reconstructed into [Ich wünsche dir eine] gute Nacht, while ellipsis (8) becomes [Ich wünsche dir eine gute] Nacht. In the short story Das Brot, the two ellipsis appear in a conversation in bed, as a ritual. The use of the ellipsis construction actually is by rights and an inevitability because the complete sentence is usually used in a formal situation. Wit this ellipsis, the author expressed the situation in bed. Therefore, it has also a expressive function.

Ellipsis (9) consists of only one word, the word doch which is a positive denial form that becomes one of the characteristics of the German language, not owned by Indonesian and English. Therefore, its use often confuses the Indonesian speaking German learners. In the short story, the ellipsis Doch is from the sentence Doch, [ich kann nur zwei Scheiben essen] or [ich kann es] 'But I can eat only two loaves'. Thus, the omitted part is a positive clause/sentence consisting of the subject ich, predicate kann... essen, and the object zwei Scheiben/es. The sentence negates a previous negative sentence, namely Du kannst doch nicht nur zwei Scheiben essen. Doch, like ja and nein, in conversation, both formal and informal are often used in form of ellipsis. In the short story Das Brot, the ellipsis has an assertive function (Busler and Schlobinski, 1997) because of the decisiveness of the wife character. But, it has also the function of intersubjectivity (White, 2013) because in that case, doch is used by the wife character to oppose her husband's opinion that she can not eat just two loaves of bread. White also stated that intersubjectivity here refers to sharing or negotiating an understanding on a strand of interaction. Thus, clearly understanding and developing a discussion on a particular topic, including expanding on topics, steering topics, elaborating on ideas construct intersubjectivity.

\subsection{Ellipsis of objects}

The object is the purpose of an event marked by a predicate. Therefore, an object can be obligatory or facultative, depending on its predicate (canoonet, Deutsches Wörterbuch und Grammatik Online). In general, an object can be a noun, a phrase, or a pronoun. The 
case is largely determined by the verb, but some are determined by the adjective. In the short story Das Brot, there are ellipsis of objects as shown in the following forms.

(10) Iss man.

(11) I ss man.

The two forms are two exact repetition sentences with the same ellipsis, the ellipsis of object. Syntactically, the verb used in both ellipsis, essen, is a transitive verb followed by a direct object or an accusative object. Contextually, the direct object refers to the phrase das Brot 'the bread'. Thus, after the reconstruction of both ellipsis, we know that the ellipsis is from an imperative sentence Iss man [das Brot]. Stylistically, the removal of objects in the imperative sentence has an economical and directive function. In the short story, das Brot 'the bread' is one of the keywords and therefore the ellipsis can be easily understood by the readers. In addition, the use of ellipsis style accompanied by the use of northern German dialect, man which has the meaning as particle like doch is a typical style of the story author who was from Hamburg. The ellipsis implies a meaning that the wife character is not patient and urges her husband to eat soon (Blume, 1988).

\subsection{Ellipsis of adverb}

Adverb is a word or phrase that describes the verb and has its own position in German sentences (Dreyer and Schmitt, 2009: 250). In the sentence, the existence of an adverb is facultative, it provides further information about the predicate. In the short story Das Brot, there are ellipsis of adverb as shown in the following forms.

(12) ...von einer Ecke in die andere.

(13) Komm man.

In ellipsis (12), the omitted word refers to a noun previously shown in the sentence, i.e. Ecke 'corner' accompanied by preposition von 'of'. Thus, ellipsis (12) is an ellipsis which refers to adverb of place and the complete sentence of its reconstructions reads... von einer Ecke in die andere [Ecke]. This ellipsis shows an expression of the author in describing the husband character. That is why, it has an expressive function. Meanwhile, for ellipsis (13), based on the verb used, the word kommen used in the imperative sentence means Come and also from the context, it can be determined that in the sentence there is deletion of place adverb. Therefore, the reconstruction result is Komm man [zu Bett]. This ellipsis (13) is an imperative sentence, accompanied by particle man indicates 
that the author avoids repeating the word used before (bed) to make the story not monotonous or to create tension (Penzo, 2010) and at the same time to clearly indicate the economic principles of language (Dwivedi, 2015) and also may show an impatience of the wife character..

\subsection{Ellipsis of main sentence}

The omitted part of the sentence may also be a sentence, main or subordinate clause. This happens when the sentence is a complex/compound sentence. In the short story Das Brot there is the following form.

(14) Dass er log nachdem sie neununddrei \ig Jahre verheiratet waren

The form (14) shows that the ellipsis Dass er log, nachdem sie neununddrei $\llbracket i g$ Jahre verheiratet waren is a subordinate clause dass-satz, a sentence constructed using a dass 'that' conjunctor. Dass-Satz serves as a Nebensatz (subordinate clause) according to the rules of the German language: a) the predicate must be placed in the final position, b) unable to stand alone, there must be a main sentence and c) there must be a comma between the main and subordinate clause. By analysis of context and syntax, it can be determined that in the ellipsis (14), the omitted part is the main sentence might consist of subject sie 'she' and predicate konnte + nicht + ertragen 'could +not+.bear. The reconstructed form can be [Sie konnte nicht ertragen], dass er log, nachdem sie neununddrei】ig Jahre verheiratet waren or Dass er log, nachdem sie neununddrei ig Jahre verheiratet waren, konnte sie nicht ertragen [She could not bear] that her husband lied after their 39 years marriage.

The ellipsis is used by the author to narrate the character of the story with an emphasis on information about what the husband character did to his wife after 39 years of marriage, he stole bread while the inventory was very limited, because he was so hungry. With the ellipsis, the author wants to attract the reader's attention and give a strong effect on the highlighted part.

\section{Conclusion}

Based on the description of the ellipsis used in the short story Das Brot, it can be concluded that there are five types of ellipsis, namely ellipsis of subject and predicate, ellipsis of subject, predicate and object, ellipsis of object, ellipsis of adverb and ellipsis of main clause/sentence. In relation to the function, it can generally also be resumed that 
the use of ellipsis in this story aims to save time. This is apparent in most of the ellipsis in the short story Das Brot which appears in the dialogue between it's characters and in the collegial language. The ellipsis becomes a stylistic device for the author because it imparts other information implicitly about the author in describing the background and the character of the story, to give a powerful effect to the readers through a deep but short description about the background and the characters of the story, as well as his emotion, notion and the mood.

\section{References}

[1] Blume, H. (1988). Zeitschrift für Germanistische Linguistik. Berlin. Vol. 16. (Jan 1, 1988):168.

[2] Bonitz, P-K. (2014). Subjektellipsen in Koordinationsstrukturen. Theoretische Fundierung und empirische Erkenntnisse. (Doctoral Dissertation). Universität Göttingen, Germany. Retrieved from http://ediss.uni-goettingen.de/

[3] Borchert, W. 1946. Das Brot. http://users.skynet.be/lit/borchert.htm.

[4] Busler, C and Schlobinski, P. (1997). Syntax des gesprochenen Deutsch. Darmstadt: Westdeutscher Verlag.

[5] canoonet, Deutsches Wörterbuch und Grammatik Online

[6] Cardin, B. (2003). Figures of Silence: Ellipses and Eclipses in John McGahern's Collected Stories. Journal of the Short Story in English [Online], 40 I Spring 2003. URL: http://jsse.revues.org/289.

[7] Dwivedi, A.V. (2015). A Study of Ellipsis in English and Hindi Short Stories. Linguistics and Literature Studies Vol. 3(6), pp. 296 - 299. Retrieved from http://www.hrpub.org/ journals/article_info.php?aid=3053,

[8] Dreyer, H and Schmitt, R. 2009. Lehr- und Übungsbuch der Deutschen Grammatik Aktuell. Berlin: Verlag für Deutsch $\mathrm{GmbH}$.

[9] Halliday, M. A. K., and Hassan, R. (1976). Cohesion in English. London: Longman.

[10] Halliday, M.A. K. (1978). Language as Social Semiotic: The Social Interpretation of Language and Meaning. London: Arnold.

[11] Jabeen, I., Mehmood, A., \& Iqbal, M. (2013). Ellipsis, Reference \& Substitution As Cohesive Devices The Bear by Anton Chekhov. Academic Research International, 4(6), 123. Retrieved from www.savap.org.pk/journals/ARInt./Vol.../2013(4.6-15)

[12] Lotze, N. (2011). Syntax: Ellipsen. Mediensprache. Retrieved from https://www. mediensprache.net/de/basix/syntax/specials/ellipsen/ 
[13] Mahalli, A.M., Valipour, P, Mahdavi, M. (2016). Translation of Ellipsis as a Stylistic Feature: Hemingway's a Farewell to Arms and its Persian Translation. International Journal of English Language \& Trans/ation Studies. 4(3). 75-80. Retrieved from www.eltsjournal.org.

[14] Menzel, K. (2016). Understanding English-German Contrasts - A Corpus-based Comparative Analysis of Ellipses as Cohesive Devices. (Doctoral Dissertation). Universität des Saarlandes, Germany. Retrieved from http://scidok.sulb.unisaarland. de/volltexte/2017/6765/pdf/Dissertation_Menzel.pdf.

[15] Merchant, J. (2013). Voice and ellipsis. Linguistic Inquiry, 44(1), 77-108. Retrieved from doi=10.1.1.591.8034\&rep=rep1\&type=pdf

[16] Müller, A. (2007). Rhetorische Figuren.Retrieved from http://www.spektrum.de/ astrowissen/rhetorik.html.

[17] Mubasyir, A.D. (2015). Ellipsis in Spoken and Written Indonesian. E-Journal WIDYA Non-Eksakta, volume 1. Retrieved from https://e-journal.jurwidyakop3.com/index. $\mathrm{php} /$

[18] Penzo, H.S. (2010). Die Kunst der literarischen Spannung. (Doctoral Dissertation), Heinrich-Heine-Universität. Düsseldorf. Retrieved from https://docserv.uniduesseldorf.de/servlets/DerivateServlet/Derivate-20028

[19] White, J. R. 2013. Ellipsis as a Marker of Interaction in Spoken Discourse. Research in Language, 11(3), 251-276. Retrieved from degruyter.com. 